\title{
Seabirds and seals as drivers of plant succession on Surtsey
}

\author{
BORGTHÓR MAGNÚSSON', GUDMUNDUR A. GUDMUNDSSON', \\ SIGMAR METÚSALEMSSON ${ }^{1}$ AND SANDRA M. GRANQUIST ${ }^{2}$ \\ ${ }^{1}$ Icelandic Institute of Natural History, Urridaholtsstræti 6-8, 210 Gardabær, Iceland (borgthor@ni.is) \\ ${ }^{2}$ Marine \& Freshwater Research Institute, Skúlagata 4, 101 Reykjavík. ${ }^{2}$ The Icelandic Seal Center, \\ Brekkugata 4, 530 Hvammstangi, Iceland.
}

\begin{abstract}
Plant colonization and succession on Surtsey have been monitored since 1965. In 2019, the 75th species of vascular plants was detected on the island, 62 species were present and about 40 species had established viable populations. Over the last decade colonization has slowed down and the number of present species not increased. The rising number of seagulls breeding on the island after 1985 had a great impact on plant colonization and vegetation development. While most parts of the island remained barren, a grassland area (13 ha in 2018) developed in the main seagull breeding colony on the southern part of the island. This development is attributed to transfer of nutrients from sea to land by the seagulls. In recent years a dense patch of vegetation, 2 ha in 2018, has also developed on the low, northern spit of the island, where a few pairs of seagulls breed in the spring and grey seals haul out and breed in the fall in considerable numbers. In a survey conducted during the grey seal pupping period in 2019, the seal abundance and spatial distribution was mapped accurately for the first time. The results show that the dense vegetation of the spit and seal distribution are clearly overlapping. The continuous shrinking of the island and its spit has led to an increasing concentration of the seals in their breeding area. Based on a literature survey we estimated the nitrogen $(\mathrm{N})$ input from sea to land by the grey seals as $9-13 \mathrm{~kg} \mathrm{~N} / \mathrm{ha}$ in 2019 . This compares to an estimated input of 5-30 kg N/ha/yr by the seagulls breeding in the same area during 2015-2019. Within the grey seal and seagull breeding area on the spit of the island, a distinct community of shore plants has developed. Measurements of plant cover and biomass in permanent plots on Surtsey in 2018 and 2019 show that development on part of the spit is reaching a similar state as in the old gull colony on the southern part of the island. This suggests that the grey seals along with the seagulls are important drivers of plant succession on the northern spit. Further research on the effects of the seals on nutrient transfer from sea to land and ecosystem development on Surtsey is recommended.
\end{abstract}

\section{INTRODUCTION}

The island Surtsey was formed in an oceanic eruption starting in November 1963 and coming to an end in 1967. The first vascular plant was found on the island in 1965 and from that time plant colonization and ecosystem development have been closely studied (Fridriksson 1975, Magnússon et al. 2009, 2014, Ólafsson \& Ingimarsdóttir 2009, Petersen 2009,
Leblans et al. 2014, Sigurdsson \& Magnússon 2014, Sigurdsson \& Leblans 2020, Aerts et al. 2020). In the early years most of the pioneering plants were shore species adapted to establishment on the sandy and nutrient poor soils of the new island. A few years after the cessation of the eruption the first pairs of seabirds started breeding on the fragile lava cliffs. 
However, during the first two decades, the progress was slow and it was evident that some ingredients of the young ecosystem were lacking. This was to change in 1986 with the formation of a seagull colony upon the southern part of the island. The plants and the birds had met and the wheels started turning. Subsequent studies revealed that the nutrient transfer from sea to land and seed dispersal by seagulls had pronounced effects on plant succession, soil development, invertebrate and bird communities, as well as ecosystem functions on the island. Over time, differences developed between the area impacted by the seagulls on the southern lava fields and other areas of the island. This is in line with what several other studies on the impact of seabirds on terrestrial ecosystems have shown (e.g. Sobey \& Kenworthy 1979, Lindeboom 1984, Ellis 2005, Havik et al. 2014, Ball et al. 2015).

The low, northern spit of Surtsey is where the first pioneering shore plants (Cakile, Leymus, Honckenya, Mertensia) were found on the island during 19651969. However, in the beginning vegetation development there turned out to be slower than on slightly higher land apparently because of frequent disturbance by coastal flooding during heavy storms in the wintertime (Friðriksson 2005). Grey seals started breeding on the northern spit as early as 1983 (Jakobsson et al. 2007) but for years it was not evident that they were impacting the development of vegetation in their breeding area. However, after 2010 this was to change. On aerial and satellite images of the island taken in 2012 or later, dense vegetation patches started to become visible on the northern spit in contrast to older images (data not shown). This needed a further investigation. Various studies have shown that seals and sea lions can impact vegetation in and around their colonies through their disturbance and nutrient transfer from the sea to land, as seabirds do (Norton et al. 1997, Farina et al. 2003, Bokhorst et al. 2007, 2019, McLoughlin et al. 2016, Moss 2017).

In this paper we report on our studies of vegetation in permanent plots on Surtsey, including the northern spit, in 2018 and 2019 and long-term trends. In mid-October 2019 we made an aerial survey and a count of grey seals in the breeding colony on the island which allowed a comparison of the seal distribution and the dense vegetation of the northern tip. The results shed a new light on vegetation development on Surtsey and possible impacts of grey seals.

\section{MATERIALS AND METHODS}

\section{Study area}

Surtsey $\left(63^{\circ} 18^{\prime} \mathrm{N}, 20^{\circ} 36^{\prime} \mathrm{W}\right)$ is in the Vestmannaeyjar archipelago off the south coast of Iceland. The islands of Vestmannaeyjar form a young volcanic system with the oldest rock formations dating from 40,000 years BP (Sigurðsson \& Jakobsson 2009). Surtsey, the southernmost of the islands, was formed in an eruption in 1963 to 1967 . At the end of the eruption the island had reached an area of $2.7 \mathrm{~km}^{2}$ and a height of $173 \mathrm{~m}$ a.s.l. During the eruption, large tephra cones were formed in explosive phases of the two main central craters. The cones were gradually transformed into denser palagonite tuff (Jakobsson et al. 2000). The southern part of the island consists of lava flows from the craters. The northern part is a low spit formed by eroded coastal sediments deposited on the leeward side (Fig. 1). Coastal erosion has taken a heavy toll of the island and by 2018 it was only 1.3 $\mathrm{km}^{2}$ in area.

The climate of the Vestmannaeyjar area is mild, oceanic and very windy. An automatic weather station has been in operation on Surtsey from 2009. For the period 2009-2019 the mean annual temperature of the island was $6.6^{\circ} \mathrm{C}$ and annual precipitation $1009 \mathrm{~mm}$. On the average the length of the frost-free period was 199 days and there were 229 days with precipitation (Petersen \& Jónsson 2020). Waters off the southern coast of Iceland are productive and rich in marine life (Astthorsson et al. 2007). Seabirds are particularly

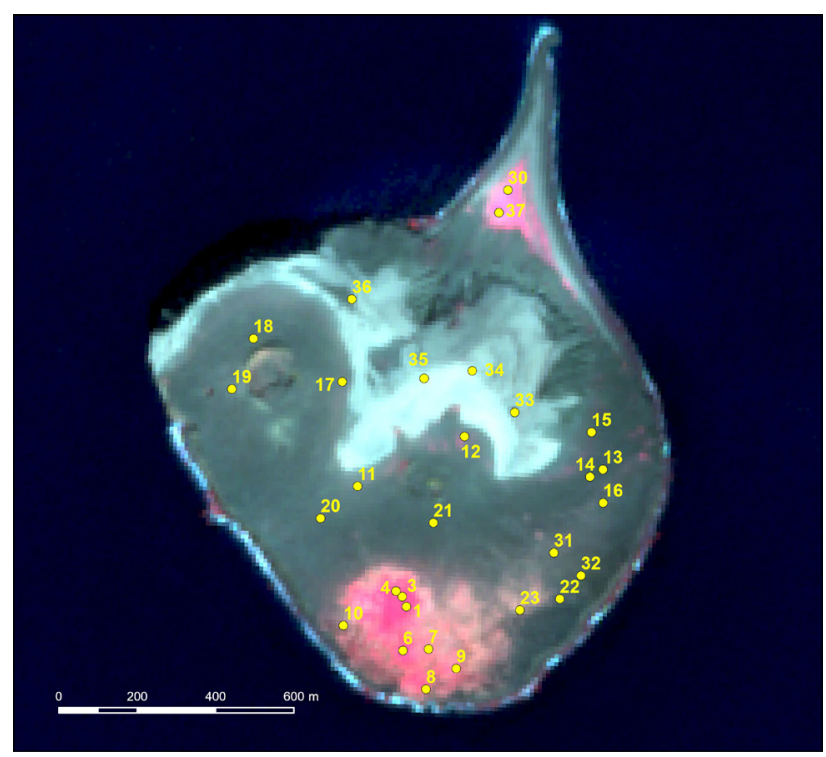

Figure 1. Surtsey and location of permanent plots (dots and numbers), infrared Sentinel image from 6 July 2019. Areas with dense vegetation appear in red color. 
abundant on the Vestmannaeyjar islands and large breeding populations of several species are found there, such as the Atlantic puffin (Fratercula arctica), northern fulmar (Fulmarus glacialis), gannet (Morus bassanus), common guillemot (Uria aalge), and black guillemot (Cepphus grylle) (Hilmarsson 2009); bird nomenclature follows the British Ornitholgists' Union (BOU 2013). The seabirds impact the vegetation with their nutrient transfer, burrowing, nest building and other activities. The vascular flora of the islands consists of some 160 species, and all but a few are present on Heimaey the largest and only inhabited island. The other old islands harbour only 2-28 species, numbers corresponding to their size, but lush seabird grasslands and cliff communities are their main vegetation types. The dominants of the grasslands are the rhizomatous grasses Festuca richardssonii and Poa pratensis. Among common species of the cliffs are Cochlearia officinalis, Puccinellia coarctata and Armeria maritima (Friðriksson \& Johnsen 1967); plant nomenclature follows Kristinsson et al. (2018). A more detailed description of the study area is given in Magnússon et al. (2014).

\section{Plant sampling and analysis of biomass}

Surtsey is visited by a team of field biologists in the middle of July every year. After the initial colonization phase, plant succession has been studied in permanent plots on the island. The first plots were set up in 1990 and the latest in 2014. The location of the plots was chosen subjectively with respect to substrate type and potential influence of seagulls on vegetation development on the island (Magnússon \& Magnússon 2000, Magnússon et al. 2009, 2014). Through the years a few plots by the northern shore have been lost due to extreme weather and surf during winter, but replacements have been made. In
2014 plots were established for the first time up on the palagonite ridges on the highest part of the island. In 2018 there were 29 plots in operation on the island (Fig. 1, Table 1). The plots are $10 \times 10 \mathrm{~m}$ in size and are sampled with line transects. Plant cover is determined by line-intercept method (see Magnússon et al. 2014).

From 1999, plant biomass is harvested every fourth year in $10 \times 10 \mathrm{~m}$ plots adjacent to the permanent plots, the last sampling occurring in 2019. In each of these plots vegetation is harvested at random coordinates. The vegetation is cut at ground level along a $2 \mathrm{~m}$ long line using electric grass clippers. All plant material is collected (green and withered) and dried at $60{ }^{\circ} \mathrm{C}$ to constant oven-dry mass in the laboratory (Magnússon et al. 2014).

A biomass estimation for the whole island in 2019 was derived from satellite data. Normalized difference vegetation index (NDVI) was calculated from a Sentinel 2 satellite image corrected for atmospheric affects, acquired 6 July, 2019 with 10 meter pixel size. NDVI is an indicator of the magnitude of photosynthetically active vegetation (Rouse et al. 1974), and it is calculated with the formula:

$$
\mathrm{NDVI}=(\mathrm{R}-\mathrm{IR}) /(\mathrm{R}+\mathrm{IR})
$$

where $\mathrm{R}$ is red reflectance and IR is infrared reflectance. NDVI values for each permanent plot were extracted and correlated against the biomass measurements (see Results). After that a biomass map was produced for the whole island from the observed relationship.

\section{Density of seabird nests}

Since 2003, density of seabird nests (mainly seagulls) has been determined annually in and around the permanent plots on Surtsey. A $1000 \mathrm{~m}^{2}$ circular area

Table 1. Permanent plots on Surtsey in 2018, year of establishment, substrate type and relative influence of seabirds and grey seals.

\begin{tabular}{lllll}
\hline Plot no. & First sampling & Substrate type & Seabird influence & Grey seal influence \\
\hline $1,3,4$ & 1990 & Sandy sheet lava & High & \\
$6-10$ & 1994 & Sheet lava & High & \\
22,23 & 1995 & Sheet lava & Moderate & \\
$11-14,16,18-21$ & 1994,1995 & Sandy sheet lava & Low & \\
15,17 & 1994 & Tephra hill slopes & Low & Moderate \\
30,37 & 2005,2014 & Coastal sand & Moderate & \\
$31-32$ & 2008 & Block lava & Moderate & \\
$33-36$ & 2014 & Palagonite, gravel & Low & \\
\hline
\end{tabular}


with a center point in the middle of each permanent plot $(10 \times 10 \mathrm{~m})$ is inspected and nest bowls, occupied in the current season counted. The great blackbacked gull (Larus marinus), lesser black-backed gull (L. fuscus) and herring gull (L. argentatus) breed in substantial numbers (200-300 pairs) upon the island (Petersen 2009) and form a dense colony on the southern part. A few fulmar nests (Fulmarus glacialis) have also been encountered within the colony and they are included in the nest counts. Fewer and more scattered pairs of great black-backed gulls also breed on the eastern- and northernmost part of the island.

\section{History of seals on Surtsey}

Two species of seals breed in Iceland; the harbour seal (Phoca vitulina) and the grey seal (Halichoerus grypus). Both species are frequently seen in the waters around the Vestmannaeyjar islands and in the early years of Surtsey they were observed in the shallow waters and on the sandy coast of the island, but records are few (Hauksson 1992). Seal populations of Iceland, including the Vestmannaeyjar area, are monitored regularly by aerial surveys. The harbour seal surveys have been conducted since 1980 and are carried out in their moulting period in July-August (Granquist \& Hauksson 2019a), while the grey seal surveys have been conducted since 1982 and are carried out during their pupping period in October-November (Hauksson 1992, 2009, 2010, 2015, Georgsdóttir et al. 2018, Granquist \& Hauksson 2019b). In recent years, only a few harbour seals have been observed on Surtsey in the harbour seal summer surveys and hardly any in the grey seal autumn surveys. However, no aerial surveys have been conducted during the harbours seals pupping period in May-June, hence there is no direct evidence of them breeding on the island.

Grey seals, on the other hand, have been reported to breed on the northern spit of the island as far back as 1983 (Jakobsson et al. 2007, Hauksson 2015). In all previously conducted surveys of Surtsey between 1986 and 2017 grey seals with pups were observed on the northern spit. Total pup production (number of pups born during the pupping period) is used as an indicator to monitor grey seal abundance. Grey seal pups are born with white lanugo fur and can be assumed to stay at the breeding site until they have moulted and weaned. Females give birth to their pups at different times over the course of a few weeks, and it can be assumed that not all pups born at the site are present at the same time, since pups born early in the period

Table 2. Observations of grey seal pups on Surtsey, based on the aerial surveys (1-5 overflights per survey) that have been carried out since 1982 (in 1998 pups were counted from land). Estimated pup production at the breeding site. Maximum number of pups and adults seen in a single survey each year and dates for maximum observations. Sources are: ${ }^{1}$ Hauksson 2015, ${ }^{2}$ Granquist \& Hauksson 2019b, ${ }^{3}$ present study. Methods applied to estimate pup production from either one or several counts are explained in Hauksson 2015 and Granquist and Hauksson 2019b.

\begin{tabular}{lccccc}
\hline Year & $\begin{array}{c}\text { Estimated pup } \\
\text { production }\end{array}$ & $\begin{array}{c}\text { Maximum number } \\
\text { of pups* }\end{array}$ & $\begin{array}{c}\text { Maximum number } \\
\text { of adults }\end{array}$ & $\begin{array}{c}\text { Date for maximum } \\
\text { observation }\end{array}$ & Source \\
\hline 1982 & & 0 & 0 & Oct 8 & 1 \\
1986 & 42 & 34 & 16 & Oct 19 & 1 \\
1988 & 20 & 15 & 11 & Nov 21 & 1 \\
1989 & 38 & 73 & 0 & Dec 13 & 1 \\
1990 & 29 & 23 & x & Nov 3 & 1 \\
1992 & 31 & 25 & 10 & Nov 2 & 1 \\
1995 & 49 & 39 & x & Oct 19 & 1 \\
1998 & x & 30 & x & Oct 15 & 1 \\
2002 & 44 & 35 & x & Nov 6 & 1 \\
2003 & 54 & 37 & Xct 29 & 1 \\
2005 & 63 & 66 & 10 & Nov 25 & 2 \\
2008 & 88 & 24 & Xep 25 & 2 \\
2012 & 62 & 55 & x & Oct 17 & 2 \\
2017 & 134 & 67 & 32 & Oct 3 & 2 \\
2019 & x & 62 & Oct 18 & 3 \\
\hline
\end{tabular}

*The maximum number of observed pups includes moulted pups, some of which might not be born in Surtsey, which explain why maximum number of observed pups is sometimes higher than estimated pup production. 
are likely to have weaned and left the area before the last the pups are born. Therefore, a breeding site needs to be surveyed a minimum of four times during the pupping period to obtain a significant estimate of total pup production (Granquist \& Hauksson 2019b). The estimated pup production on Surtsey has varied from 20 to 134 and the maximum number of pups seen in a single flight within a year has ranged from 15 to 73 (Table 2), (Hauksson 2015, Granquist \& Hauksson 2019b). In the latest grey seal survey in Iceland, which was carried out in 2017, the breeding colony on Surtsey was the largest of all colonies at the south coast with an estimated pup production of 134 (Table 2) and the peak of the pupping period occurred on October 12 ( \pm 1 day) (Granquist \& Hauksson 2019b).

\section{Distribution of the grey seals in their breeding colony in 2019}

To document the distribution of grey seal pups and adults, the colony was photographed vertically from an aircraft, flown in calm weather at $530 \mathrm{~m}$ (1680 feet) altitude, around noon on 18 October, 2019. The twin engined Partinavia P-68 Observer aircraft has a hatch in the floor where cameras can be mounted for vertical photography. We used two Canon EOS 5DS R 50.2 MP digital cameras with $50 \mathrm{~mm}$ and 105 $\mathrm{mm}$ lenses. The programme DotDotGoose (version 1.1.0; Ersts 2019) was used to count the seals from the digital photos. A map was then made showing the seal locations on top of a layer of vegetation distribution of the northern spit.

On 30 October, 2019 a short visit by helicopter was made to the island which allowed a brief walk through and photographing of the seals in their breeding colony.

\section{Changes in island area and patches of dense vegetation based on images}

From the early years of the eruption aerial photographs have been taken regularly of Surtsey, bi-annually during the last decades. The photographs have allowed exact monitoring of the erosion of the island and surface changes (Jakobsson et al. 2000). Also, changes in plant cover are noticeable in areas where dense vegetation patches develop. They become visible when total plant cover reaches approximately $20 \%$ or more. This has been most obvious on the southern part of the island where a gull colony started to form in 1986. On an aerial photograph from 1988 the first sign of a dense patch of vegetation could be seen in the center of the gull colony. From that year expansion of the dense vegetation area was followed (Magnússon et al. 2009, 2014). After 2010, a patch of dense vegetation also became visible on the low spit on the northern part of the island, on aerial and satellite images. By 2014 small, dense patches of vegetation were visible at old fulmar nest sites in crater walls in the center part of the island. Here we update the development of dense vegetation areas on the island by analysing the series of aerial photographs from 2014, 2016 and 2018. Approximate outlines of the dense vegetation patches, as seen on the aerial photographs (true color) were drawn and changes followed between years. The outlines of the island and the northern spit were also drawn. The northern spit is the only part of the island with low shores, as the southern part has high vertical cliffs. In the geospatial information system ESRI Arc Gis the 10 $\mathrm{m}$ contour line and the shoreline for each available year were used to construct a polygon representing the spit. The shoreline was drawn manually so that the software could calculate the area of the polygons for each year.

\section{Data analysis}

Vegetation data (vascular plants only) sampled in the permanent plots on Surtsey in 2018 were analysed with a two-way cluster analysis. The cover data were transformed $(\log +1)$ prior to analysis. The PC-Ord 6 package (McCune \& Mefford 2011) was used for the analysis with the Euclidean distance measure chosen and clustering by Ward's method. Plant grouping, cover and biomass were compared to seabird and grey seal distribution.

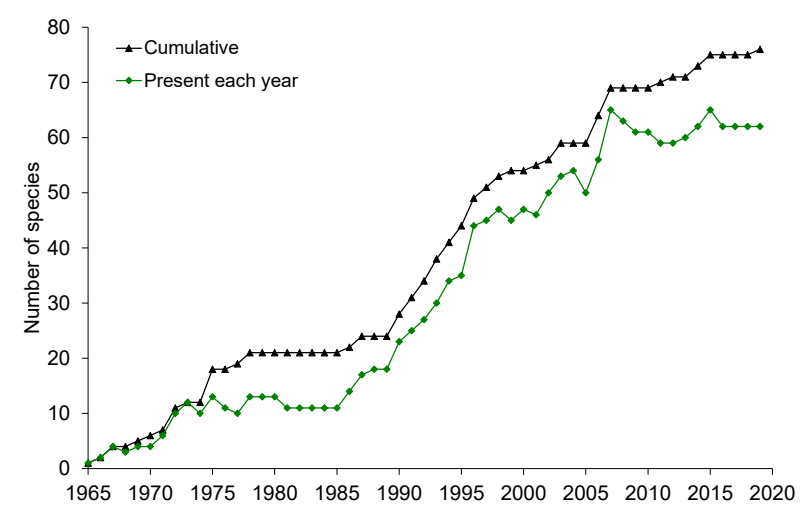

Figure 2. Surtsey colonization curve for vascular plants during the period 1965-2019. 


\section{RESULTS}

Vegetation: colonization, plant composition and grouping, cover and biomass

By 2019 a total of 76 vascular plants species had been discovered on Surtsey from 1965 and of those 62 had living individuals. One new species, Tussilago farfara, was found on the island for the first time in 2019. About 40 species had established viable populations. After two distinct colonization phases during approximately $1965-1975$ and $1987-2007$, colonization has slowed down over the last decade (Fig. 2).
In the sampling of the 29 permanent plots $(\mathrm{P})$ on the island in 2018 (Fig. 1), 25 vascular plant species were recorded. The number of species within individual plots varied from 3 to 16 . Poorest in species was P32, located on block lava on the eastern part of the island. Richest in species was a nearby P23 at the fringe of the gull colony, on sheet lava (Fig. 1).

The cluster analysis revealed four main groups in the plot assemblage (Fig. 3). The first group, G1, consisted of three plots (P1, 3 \& 4) within the gull colony that are characterized by a very dense and

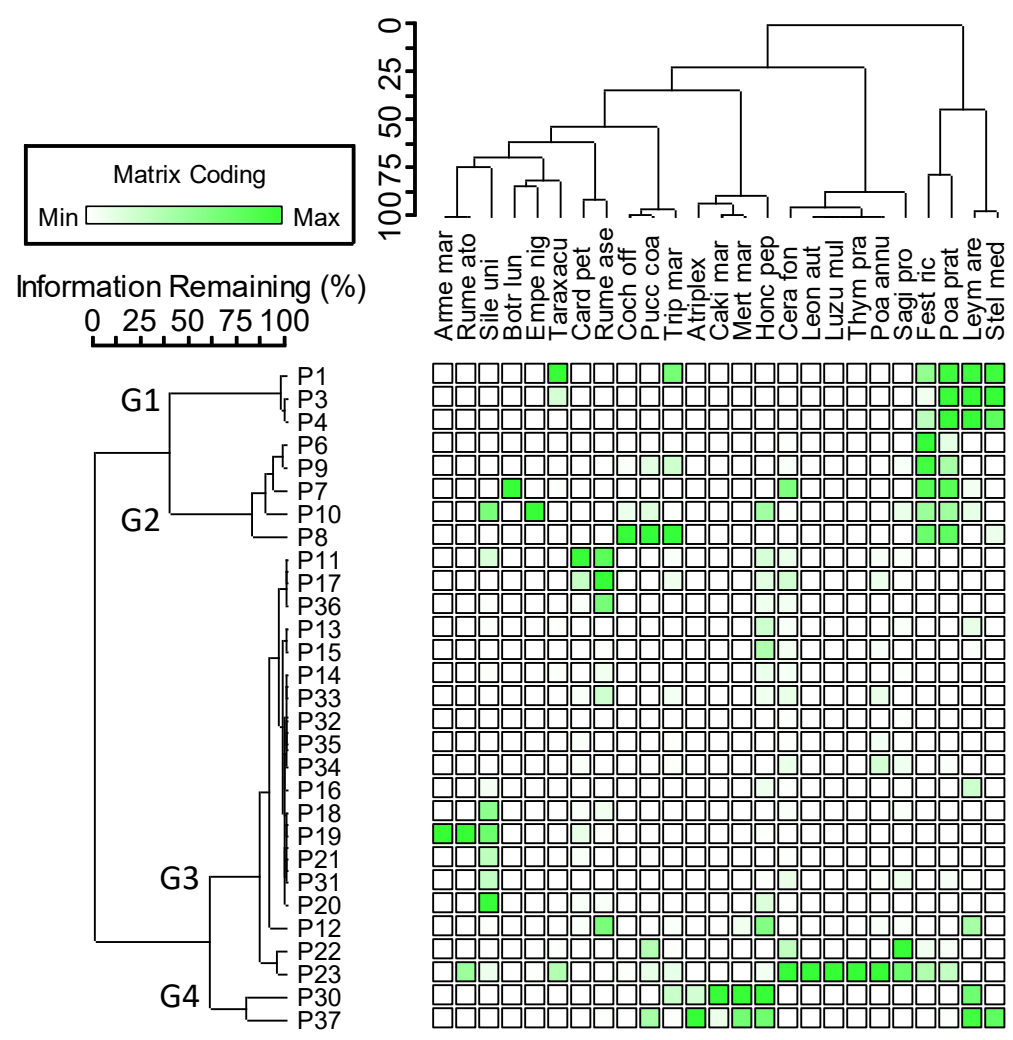

Figure 3. Two-way cluster analysis graph showing grouping of plots (left) and plant species within them (above) on Surtsey in 2018. The species are from left to right: Armeria maritima, Rumex acetosa, Silene uniflora, Botrychium lunaria, Empetrum nigrum, Taraxacum sp., Cardaminopsis petrea, Rumex acetosella, Cochlearia officinalis, Puccinellia coarctata, Tripleurospermum maritimum, Atriplex sp., Cakile maritima, Mertensia maritima, Honckenya peploides, Cerastium fontanum, Leontodon autumnalis, Luzula multiflora, Thymus praecox, Poa annua, Sagina procumbens, Festuca richardsonii, Poa pratnesis, Leymus arenarius and Stellaria media. Relative abundance of each species within a plot is shown by green color intensity, irrespective of other species.

Table 3. Species richness and total plant cover (\%) in permanent plots in 2018 and plant biomass $\left(\mathrm{g} \mathrm{dwt} . / \mathrm{m}^{2}\right)$ harvested in 2019. Averages \pm s.e. for the four vegetation groups (G1-G4) of the cluster analysis and for all the plots.

\begin{tabular}{lllll}
\hline & $\mathrm{n}$ & Species richness & Plant cover & Biomass \\
\hline G1 & 3 & $5.0 \pm 0.5$ & $160.6 \pm 5.3$ & $576.0 \pm 20.1$ \\
G2 & 5 & $8.0 \pm 1.0$ & $78.1 \pm 12.2$ & $231.7 \pm 85.1$ \\
G3 & 19 & $7.1 \pm 0.6$ & $2.9 \pm 1.0$ & $7.4 \pm 1.9$ \\
G4 & 2 & $9.0 \pm 1.4$ & $88.3 \pm 4.8$ & $222.7 \pm 17.5$ \\
All plots & 29 & $7.2 \pm 0.5$ & $38.4 \pm 10.0$ & $119.7 \pm 36.7$ \\
\hline
\end{tabular}




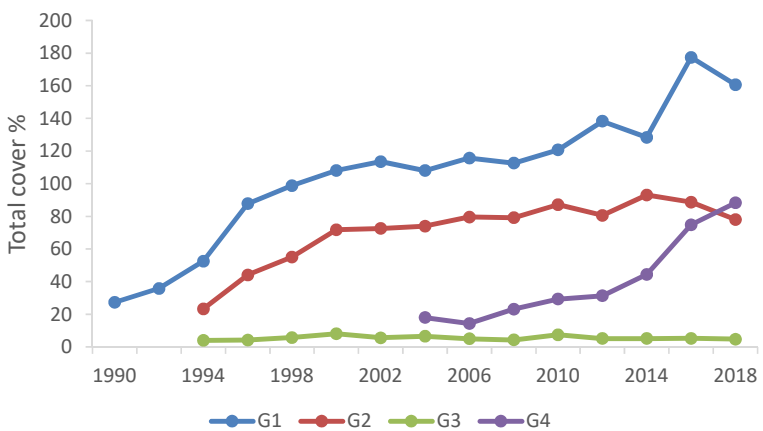

Figure 4. Total plant cover in permanent plots from their establishment. Averages for the four groups (G1-G4) formed in cluster analysis of the 2018 vegetation data, shown in Fig. 3. G1 and G2 plots are within the main gull colony, G3 are outside the colony and G4 are on the northern spit where the grey seal colony hauls out.

layered cover of Leymus arenarius, Poa pratensis and Stellaria media, along with less abundant Festuca richardsonii, Taraxacum sp. and Tripleurospermum maritimum. Total plant cover and biomass was two-

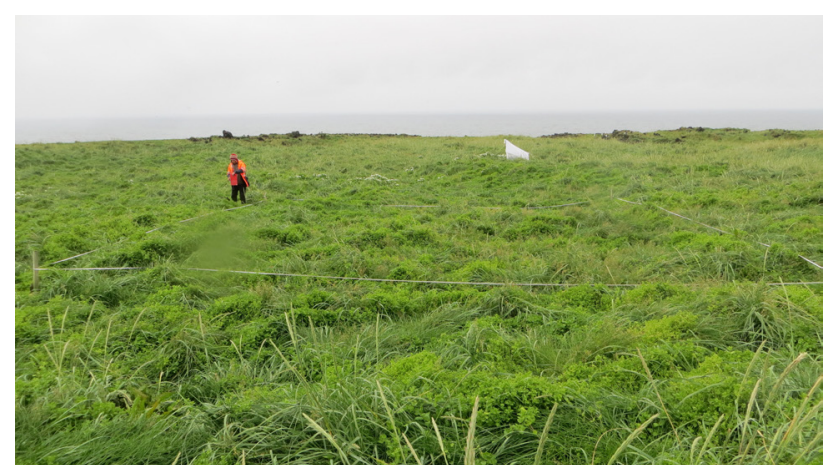

G1-plot 3. Plant cover: $170 \%$, biomass: $603 \mathrm{~g} / \mathrm{m}^{2}$, dominants: Poa pratensis, Leymus arenarius, Stellaria media.

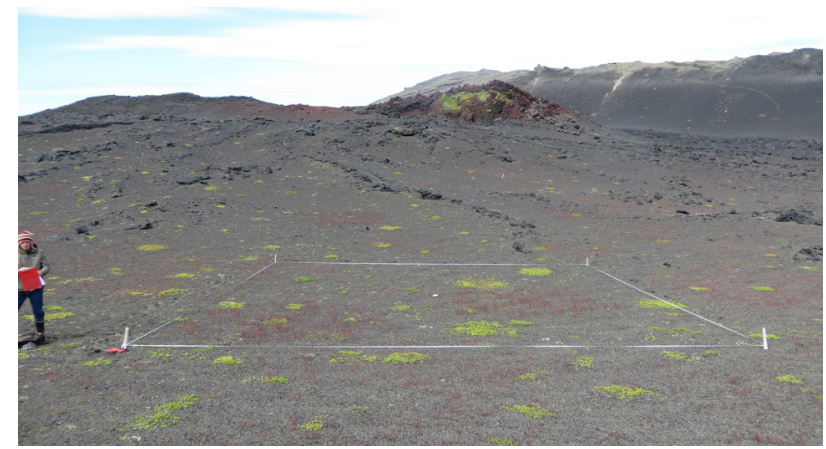

G3-plot 17. Plant cover: 4\%, biomass: $10 \mathrm{~g} / \mathrm{m}^{2}$, dominants: Rumex acetosella, Honckenya peploides, Cerastium fontanum. fold higher than in any of the other groups and species richness is relatively low (Table 3 ). The plots are in the old center of the gull colony and on relatively thick tephra soil that overlays the lava underneath.

The second group, G2, consisted of five plots (P610) that are also within the gull colony but on lava substrate with little or no tephra on top. The vegetation was lower and not as dense as in G1 as shown by the plant cover and biomass but species richness was higher (Table 3). The most common species of this group (G2) were the grasses Festuca richardssonii and Poa pratensis but other common species were Puccinellia coarctata, Tripleurospermum maritimum and Cochlearia officinalis (Fig 3).

The third group, G3, consisted of 19 plots (P1129, 31-36, Fig. 3). These plots are outside the gull colony and on variable substrate (Table 1). They had a very low plant cover and biomass but species richness is intermediate (Table 3). The main species in tephra plots of the group were Honckenya peploides, Cerastium fontanum, Silene uniflora,

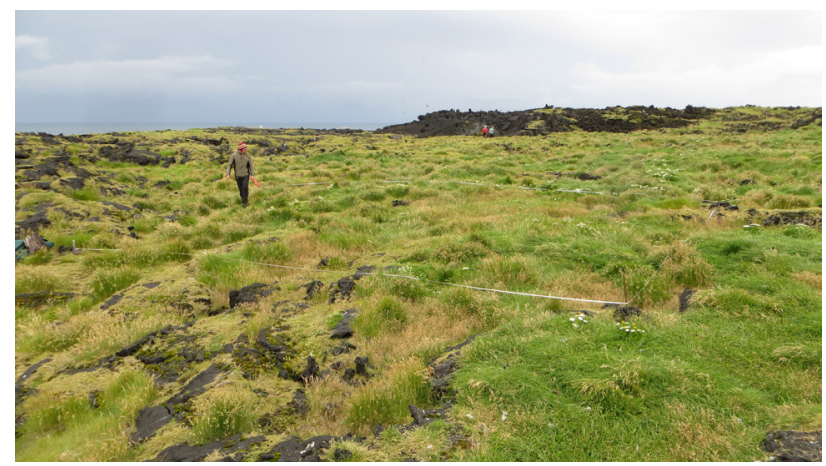

G2-plot 8. Plant cover: $89 \%$, biomass: $169 \mathrm{~g} / \mathrm{m}^{2}$, dominants: Poa pratensis, Festuca richardsonii, Puccinellia coarctata.

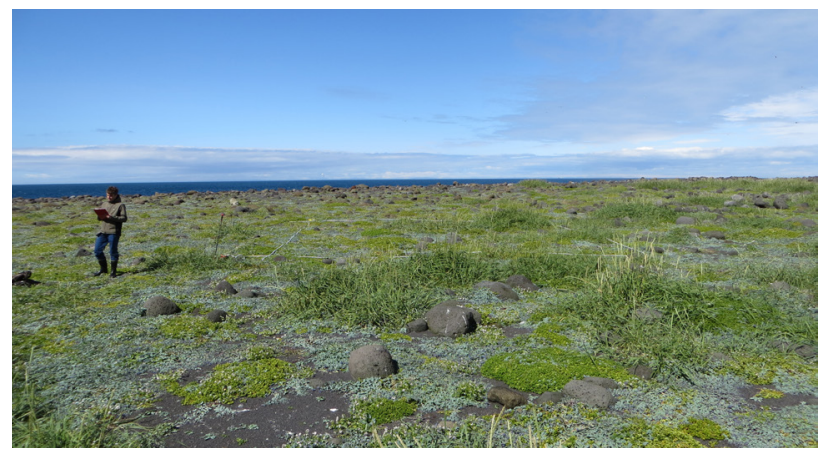

G4-plot 30. Plant cover: 95\%, biomass: $248 \mathrm{~g} / \mathrm{m}^{2}$, dominants: Mertensia maritima, Honckenya peploides, Leymus arenarius.

Figure 5. Examples of plots within the four main vegetation groups, in 2018 (see Fig. 3). Cover data is from the 2018 season and biomass from 2019. G1 and G2 are within the old gull colony, G3 is outside the colony and G4 is from the grey seal and gull breeding area on the northern spit. Plant cover is a total cover of species within plot, adds to $>100 \%$ in dense, layered vegetation. Photos: Borgthór Magnússon 16-18 July 2018. 


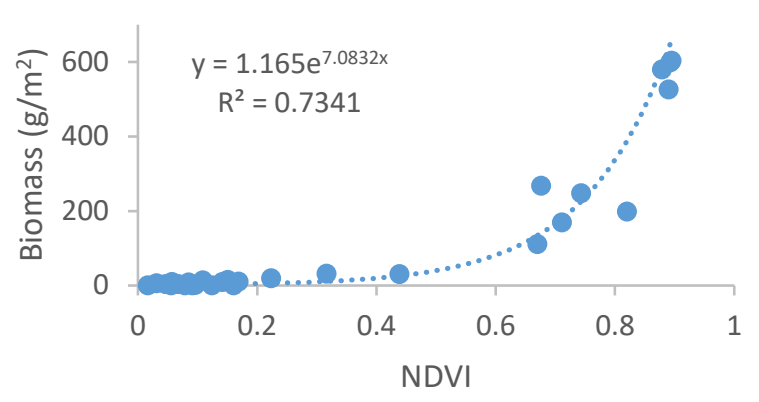

Figure 6. Relationship between plant biomass of permanent plots on Surtsey in mid July 2019 and NDVI of their pixels acquired from a Sentinel 2 image dated 6 July 2019 (see Fig. 1).

Rumex acetosella and Cardaminopsis petrea, but in plots on lava or the palagonite ridges Puccinellia coarctata, Cerastium fontanum, Sagina procumbens and Poa annua.

The fourth group, G4, consisted of only two plots $(\mathrm{P} 30,37)$ that are both on the low, northern spit (Figs. 1 and 3). Within these plots, plant cover, biomass and species richness were relatively high (Table 3 ). The characteristic species of the plots were the shore plants Mertensia maritima, Cakile maritima, Atriplex sp., Honckenya peploides and Leymus arenarius, but other rather abundant species were Stellaria media and Puccinellia coarctata in one of the plots. The annuals Cakile maritima and Atriplex sp. were not found in other plots on the island.

The long-term data from the vegetation plots revealed trends in development within them (Fig. 4). A comparison of the four vegetation groups (G1-G4) shows that from as early as 1994 , the cover of plots within the gull colony (G1 and G2) increased more or less steadily over time, while that of plots outside the colony (G3) has remained extremely low. In the plots on the northern spit (G4), cover was relatively low in 2004 and 2006 but started to increase from 2008 and took a sharp rise in 2014.

Sampling of biomass adjacent to permanent plots in 2019 reflected the same differences between plots and groups as the species composition and cover measurements in 2018 (Table 3). The biomass in individual plots varied from $<1$ to $603 \mathrm{~g} \mathrm{dwt} / \mathrm{m}^{2}$, the poorest plots (P33 \& 35) being upon the palagonite ridge, and the richest (P3) in the lush grassland of the gull colony. Examples of plots within the four vegetation groups are shown in Fig. 5, underlining the differences in their plant composition, cover and biomass.

The biomass measurements from the middle of

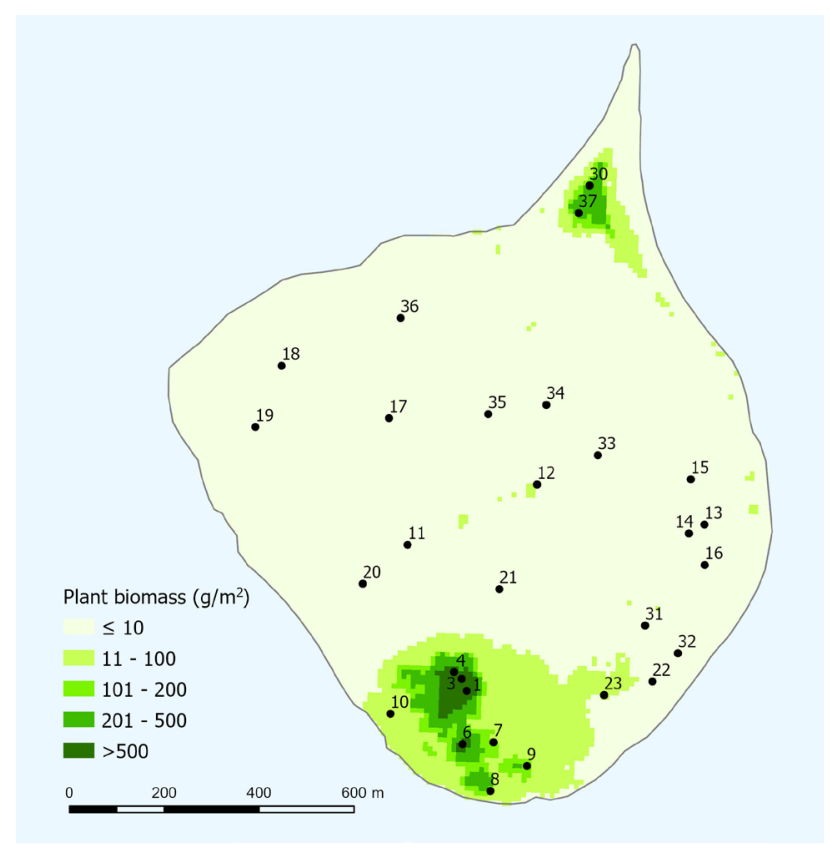

Figure 7. Distribution of plant biomass (dry weight) on Surtsey in 2019, derived from projected NDVI-values and ground-truth biomass measurements by the permanent plots in the same season (see Fig. 6). Hot spots are the seagull colony on the southern part of the island and the grey seal/seagull breeding area on the northern part. Most of the light-green spots on the center part of the island are small breeding colonies of fulmars. Furthest to the right are two old seagull nest sites within Leymus-dunes.

July 2019 allow a calibration with NDVI-values of a Sentinel-image covering the island a week earlier. The correlation showed a good exponential relationship between biomass and NDVI (Fig. 6). A new dataset derived by using the best-fit exponential function from the correlation $\left(\mathrm{y}=1.165 \mathrm{e}^{7.0832 \mathrm{x}}\right.$, EXCEL) gave an estimation of biomass for each pixel in the dataset. The outcome is shown on Fig. 7. Over most of the island, biomass was extremely low, but on the other hand, very high within the gull colony on the southern part of the island, as well as in part of the northern spit. A few other areas showed small patches of elevated biomass (Fig. 7). A summing up of these calibrated values gave a biomass of $19,600 \mathrm{~kg}$ dry weight for the whole island in 2019.

\section{Vegetation: expansion of dense growth}

With inspection of the series of aerial photographs of Surtsey it is possible to trace and follow the formation and development of dense vegetation patches on the island (Figs. 8 \& 9). In 1988 the first patch within the gull colony on the southern part of the island 
measured 0.03 ha (Fig. 8). Ten years later, in 1998, it had expanded to 6.6 ha, and by 2014 it had reached 13.0 ha. The 2016 and 2018 outlines revealed a small reduction due to an erosion of the island (Fig. $8 \& 9$ ).

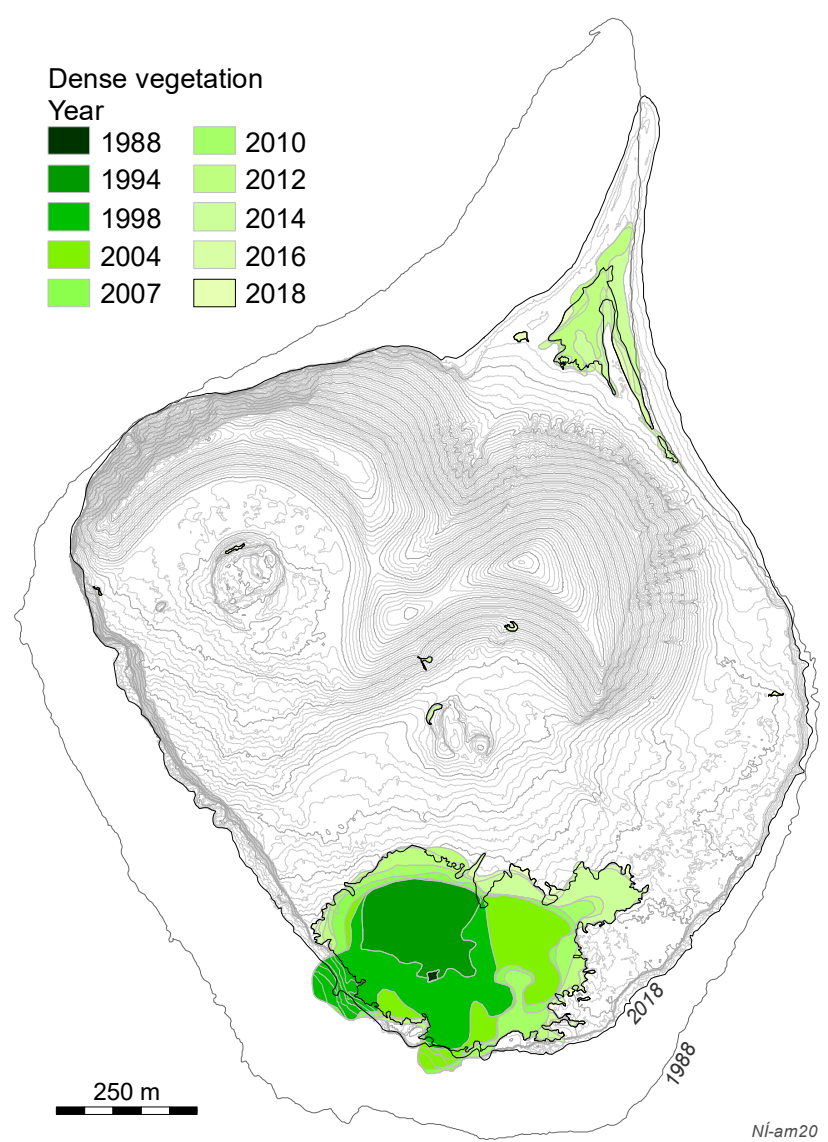

Figure 8. Expansion of dense vegetation on Surtsey during the period 1988-2018. Approximation from aerial images, by Anette Th. Meier. First signs of dense vegetation became visible in 1988 on the southern part of the island, in 2012 on the northern part and in 2014 on the central part. Vegetation patches become visible on aerial photos when plant cover has reached about $20 \%$ or more. Contour lines are $2 \mathrm{~m}$.

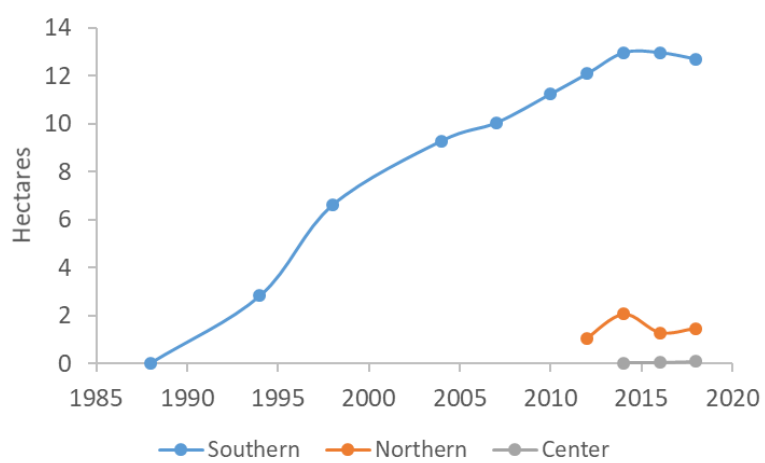

Figure 9. Development of areas of dense vegetation patches on southern, northern and center Surtsey during 1988-2018, as seen and outlined on aerial photographs, see Fig. 8.
On the northern spit a dense vegetation patch of 1.1 ha had become visible in 2012, expanding to 2.1 ha in 2014. After that a reduction in area occurred and it measured 1.5 ha in 2018 (Fig. 8 \& 9). The small patches on the center part of the island measured only 0.1 ha in 2018. The total area of dense vegetation patches on the island in 2018, as outlined from aerial photographs, was 14.3 ha in 2018 or approximately $11 \%$ of the island's area.

\section{Seagull nesting density by vegetation plots}

From 2003 we have an unbroken 17-year record of nesting density in and around the permanent plots on Surtsey. The total number of nests found each year varies greatly (19-52), being lowest in 2009 and highest in 2017 (Fig. 10). The variation probably reflects feeding conditions in the sea around Surtsey in the spring and during the breeding season. Through the years most of the nests have been within the gull colony area on the southern part of the island. From 2015 nests have also been encountered near plots on the northern spit (Fig. 10).

Average nesting density in plots within the four vegetation classes shows a distinct difference between the plots as well as a change in trends between 2003 and the present (Fig. 11). However, one must bear in mind that nests were not counted during the first 17 years of the gull colony. From 2003 nesting density was high within the two groups, G1 and G2, consisting of plots within the gull colony. The density was markedly higher in G2 but plots within the group are located more towards the edge of the colony than plots in G1 (Fig. 1). Nesting density in the other two groups,

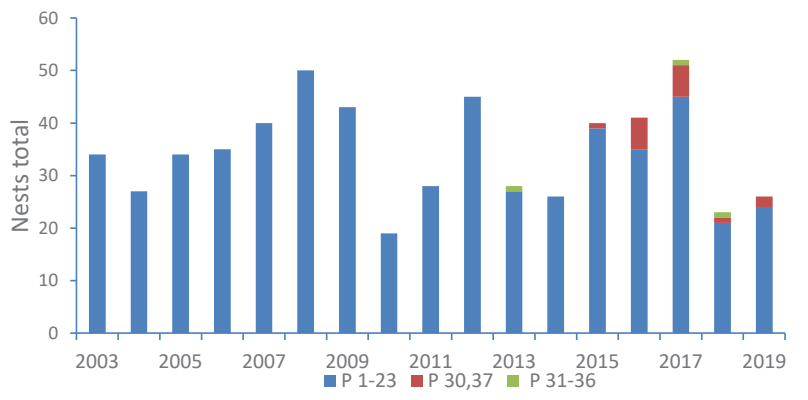

Figure 10. Total number of nests found in a $1000 \mathrm{~m}^{2}$ circular area by all permanent plots (P1-36) on Surtsey from 2003 to 2019. P1-23 are 21 plots in operation from 2003. P30-37 are 8 plots established in 2013 or later, but prior nesting is improbable. P30 and P37 are on northern spit, (see plot locations on Fig. 1). The nests are all seagull nests except for the years 2012, 2013, 2014, 2018 and 2019, when 1-2 fulmar nests were also found each year and included. 


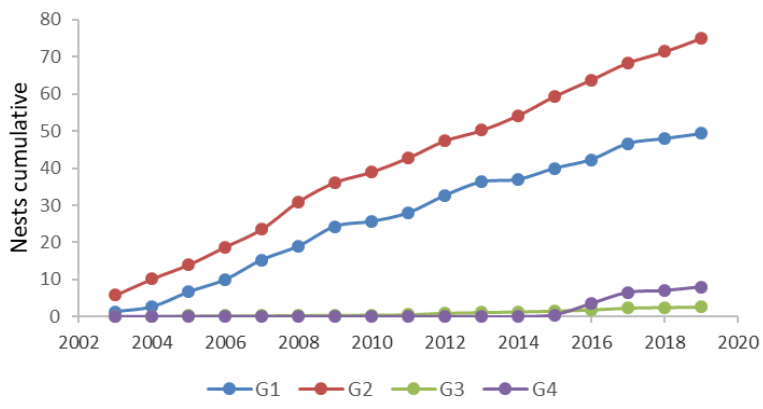

Figure. 11. Cumulative number of gull nests in and around permanent plots from 2003 to 2019 (within a circular area of 1000 $\mathrm{m}^{2}$ ), averages for the four groups formed in cluster analysis of the 2018 vegetation data (see Fig. 3).

G3 and G4, remained extremely low over most of the period but from 2016 there was a slight rise, especially in the plots of G4, on the northern spit (Fig. 11).

\section{Grey seal numbers and distribution in 2019}

In the aerial survey of Surtsey on 18 October 2019, a total of 94 grey seals was observed on the island, all on the northern tip. Of those 62 were pups and 32 adults. Several females were seen feeding their pups. The seals were on the inner part of the spit and most of them inside the coarse boulder ridge by the shore. The ridge extends to form the northernmost part of the spit where seals were

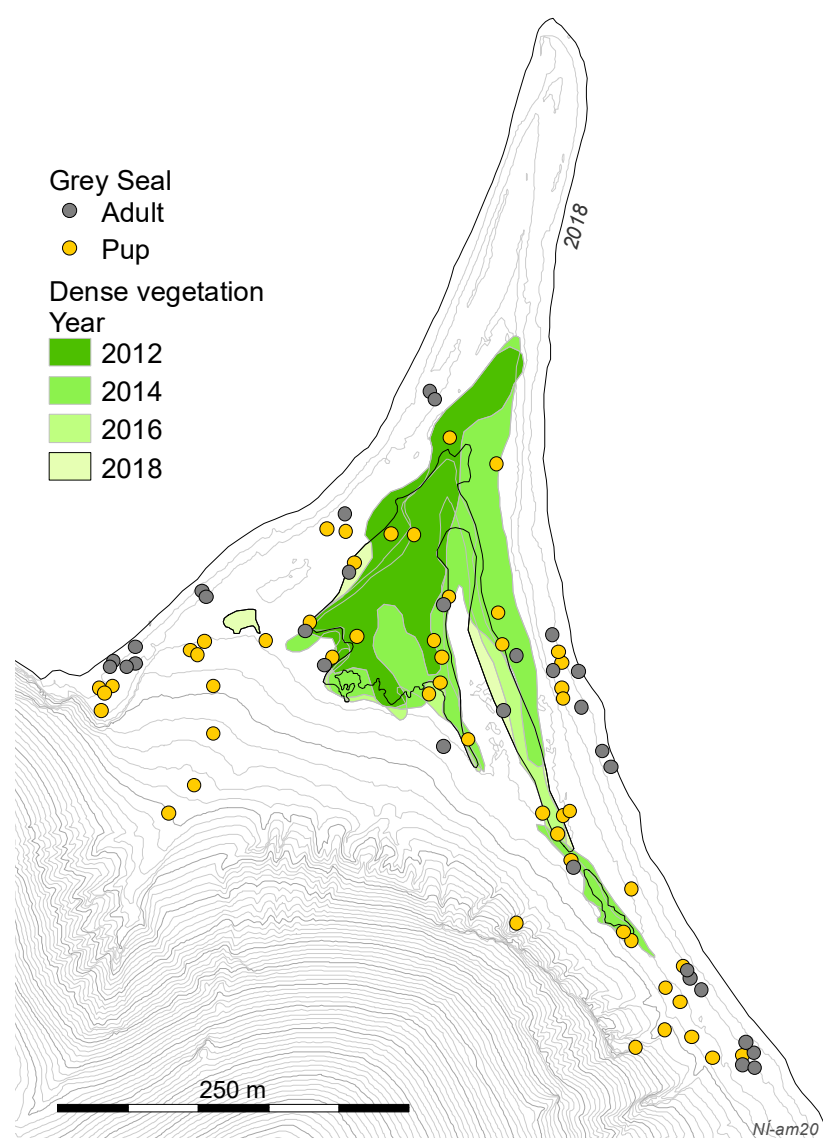

Figure 12. Distribution of grey seals photographed in an aerial survey of Surtsey on 18 October 2019. The expansion of dense vegetation on the northern spit of the island from 2012 is also shown. Approximation from aerial images, by Anette Th. Meier. Contour lines are $2 \mathrm{~m}$.

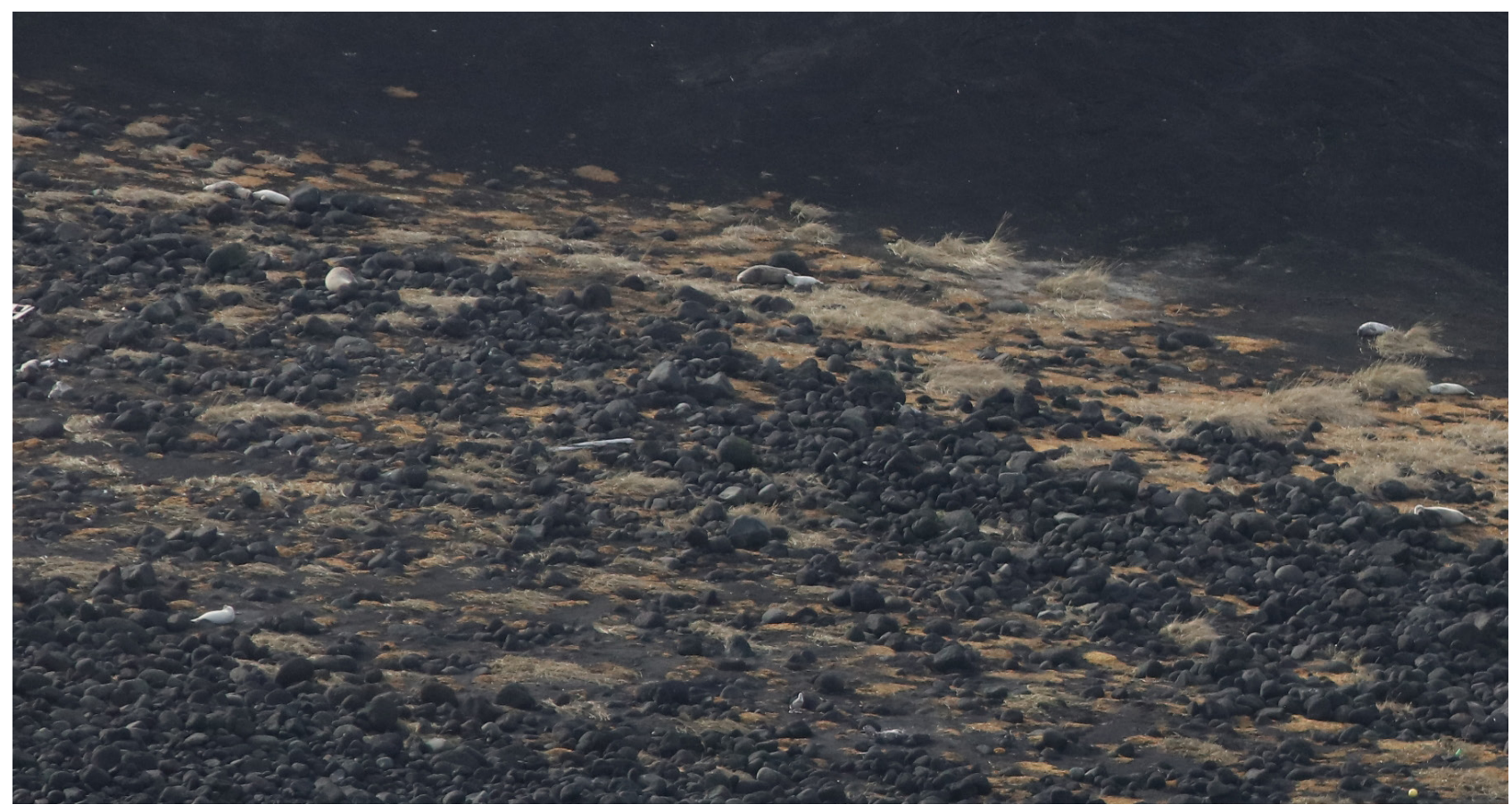

Figure 13. Grey seals by the northern shore of Surtsey on 18 October 2019. A female with a suckling pup is in the center of the photograph. Four adults and six pups are visible. The withered vegetation is mainly Leymus and Honckenya. Photo: Gudmundur A. Gudmundsson. 


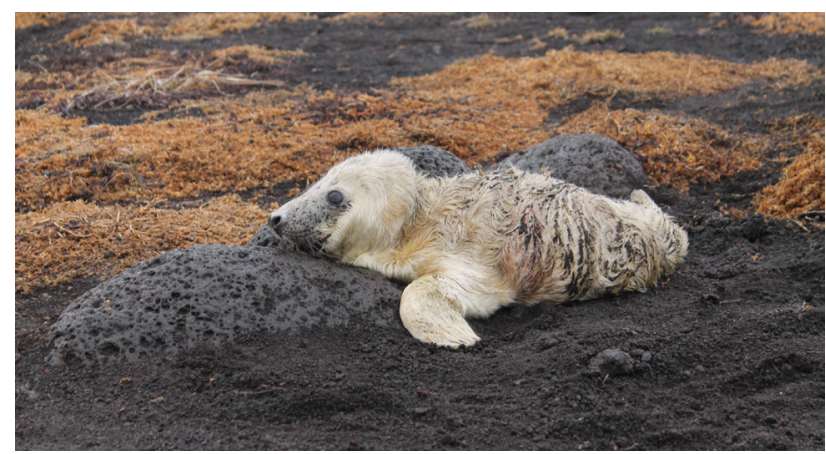

A. A newborn pup in a bed of Honckenya on the northern spit.

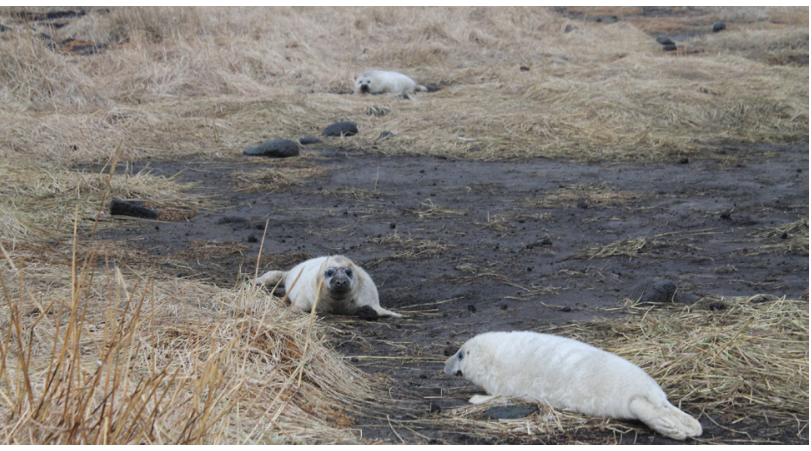

C. Roughly 2-week-old pups within the dense vegetation area of the northern spit

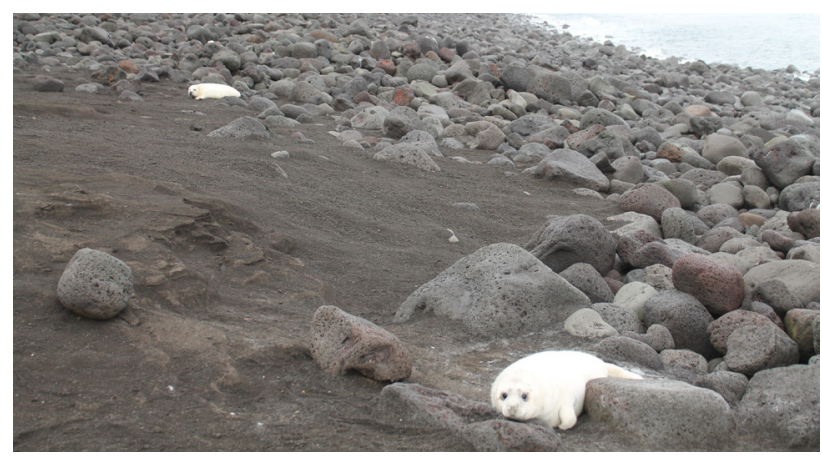

B. Pups, about 1-week-old on a tephra slope on the eastern side of the spit.

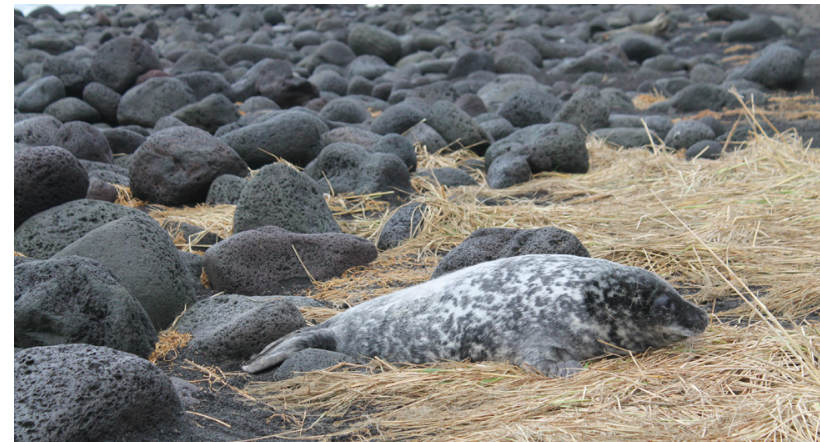

D. Pup about 4-week-old in a bed of Leymus on the eastern side of the spit. The dense white birthcoat is gone and adult fur has developed.

Figure 14. Grey seal pups at different stages of development by the northern shore of Surtsey on 30 October, 2019. Photos: Borgthór Magnússon.

not seen (Fig. 12). Many of the pups and adult seals were within or near the dense vegetation in the central part of the spit (Fig. 12-14). A few of the pups were up in tephra channels on the slopes above the spit. None of these pups were with their mothers which can indicate that they were weaned. At the later stages of the moulting period, the pups start crawling around and exercising their muscles before going to sea.

In the brief visit to the island on 30 October, 2019 it was not possible to thoroughly inspect the whole seal colony. However, pups at different development stages were encountered, from newborns to 4-5 week old pups (Fig. 14). Also, several adult seals were observed, including a female with fresh feces beside her who appeared ready to give birth.

\section{DISCUSSON}

Vegetation development

The finding of Tussilago farfara on Surtsey in 2019 is the first addition to the vascular flora since 2015 . The species has probably been dispersed by wind to the island. From our last account of the flora reaching to 2013 (Magnússon et al. 2014) four other newcomers have been discovered. They are Ranunculus repens, Epilobium hornemannii, Alchemilla alpina and Carex bigelowii. However, only the last one was present in 2019. There is now a strong indication that the colonization wave driven by the seagulls during 19872007 has slowed. The number of present vascular plant species on the island peaked at 65 in 2007, then began to decline. From 2016 to the present the number has stayed at 62 species.

The analysis of the vegetation data sampled in 2018 showed mostly the same trends and differences between areas outside and inside the old seagull colony as revealed in our previous studies (Magnússon \& Magnússon 2000, Magnússon et al. $2009,2014)$. In 2018/2019, there was $\sim 50-80$ times as much cover and biomass in areas with breeding gulls as those where no gulls were present. This change is driven by nutrient transfer from sea to land by the birds. Most important are $\mathrm{N}$ and $\mathrm{P}$, but availability of several other nutrients is enhanced in the affected soils (Sigurdsson \& Leblans 2020, Aerts et al. 2020).

New in our results of the vegetation analysis of 2018 is that the plots (P30 \& P37) on the northern spit are departing from other plots outside the old gull 
colony, indicating a recent change in the vegetation of the spit. The plots are in the center and lowest part of the spit, where there is more shelter and moisture compared to outer parts of the area. What is most noteworthy among their species is a great increase in the abundance of Mertensia maritima in both plots since 2016, also in the abundance of Cakile maritima, Atriplex, Stellaria media and Leymus arenarius in one or both plots. All the species are known to prefer fertile to richly fertile soils (Nitrogen (Ellenberg) 6-8) according to BRC (2020). Cakile, Atriplex and Stellaria are annuals that only thrive in relatively nutrient rich environments.

Cakile was the first species found on Surtsey, on the northern shore in 1965 (Friðriksson 1975). In the following years it came and went until 1995, as it was present in 13 years out of 30 (Magnússon et al. 2009). From 1995 there is an unbroken record of the species on the island (unpublished data). In 2014 it started to appear in the plots on the northern spit and increase in abundance. Mertensia has an unbroken record of presence on the island from 1971 but does not start to flourish until 2014, in the plots of the spit. Although found earlier Stellaria did not gain a foothold on the island until 1988. Its main stronghold became the oldest and richest plots within the gull colony, until it appeared in high abundance in one of the plots on the northern spit in 2018. Atriplex has an unbroken record on the island from 2004. It is mostly confined to the dense vegetation on the northern spit were it has thrived in recent years. Leymus was the second colonizer of Surtsey, in 1966, and has an unbroken presence since 1973. It has spread widely in sandy areas and in 2012 it was among the most common species on the island (Magnússon et al. 2014). However, its abundance, measured as cover within permanent plots, remained relatively low except in areas impacted by breeding seagulls. Since 2016, its abundance has increased substantially within the plots on the northern spit. The observed changes in distribution and abundance of these species on the northern spit in recent years indicate considerable increase in soil fertility of the area. The low, northern shores of Surtsey receive very little drift of marine algae, as large fucoid beds have not developed on the unstable, littoral substrate off the spit (Jakobsson et al. 2007). Nutrient input upon the beaches and further inland is therefore considered limited via transport of dead algae from the sea.

\section{Distribution of seagulls and seals}

The first record of seagulls breeding on the northern spit is from 2005 when one great black-backed gull nest was found (unpublished data). From that time a few pairs have nested in the area amongst driftwood and patches of Honckenya. The first nest in or near a permanent plot on the spit was found in 2015. In 2016 and 2017, there were 6 nests recorded in or near the two plots, during a peak in number of breeding gulls on the island. In 2018 and 2019 the number of nests in or near the two plots was down to 2 and 1 (Fig. 10). It can therefore be stated that the seagulls have impacted the vegetation of the northern spit in recent years.

In this study, we have created the first map of the exact distribution of the grey seal breeding colony on the northern spit of Surtsey, which is the only part the island accessible to them. While the map is based on a single overflight, previous data obtained from the regular grey seal censuses carried out since 1982, has shown the grey seals with pups haul out on the northern spit (Granquist and Hauksson 2019b; Erlingur Hauksson pers. comm.). As an example, images taken during the census of 5 October 2017, show dozens of grey seal females and pups, most of them at the eastern and western edges of the spit, under the hill slopes, similar to what we observed in the current study (Granquist and Hauksson, unpublished data). Fewer seals were visible near the center of the spit in early October 2017 compared to late October 2019. In both years many seagulls ( 75 glaucous, 46 great blackbacked and 12 herring gulls in 2019) could be seen on the photos of the spit, some of them amongst the seals and others roosting on the northern tip of the spit. This suggests that the gulls might be attracted to something edible coming from the seals.

Due to continuing marine abrasion, the land surface of Surtsey was reduced from its maximum area of $2.7 \mathrm{~km}^{2}$ in 1967 to $1.3 \mathrm{~km}^{2}$ in 2018 . The northern spit, where the grey seals haul out to breed, has shrunk accordingly. In 1967 it was $0.3 \mathrm{~km}^{2}$ or about 30 ha in area (Jakobsson et al. 2000). In 1988 it was reduced to 20.1 ha and by 2018 down to 10.2 ha (Fig. 8, Fig. 15). The grey seals in the breeding colony have therefore concentrated in a smaller area with the passing of time.

It should be noted that estimated total pup production (see Table 2) is a better indicator for grey seal abundance in Surtsey, than a separate single count, which was only possible in 2019. In 2017, when four overflights were 


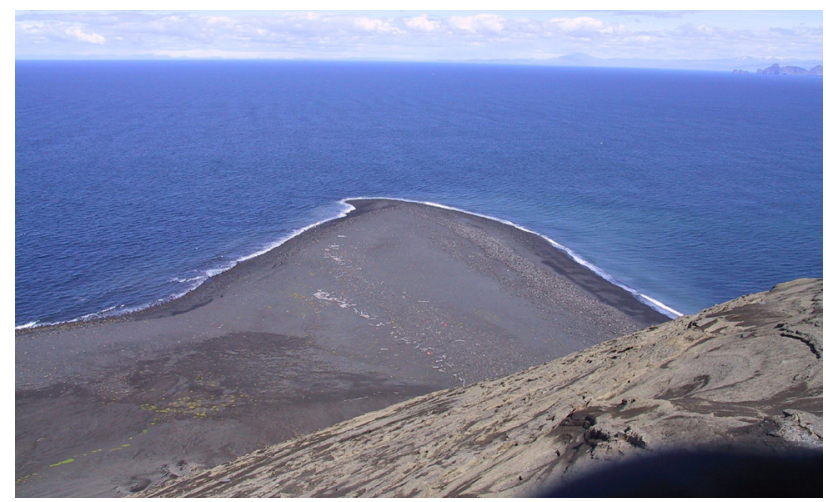

A. 27 July, 2001.

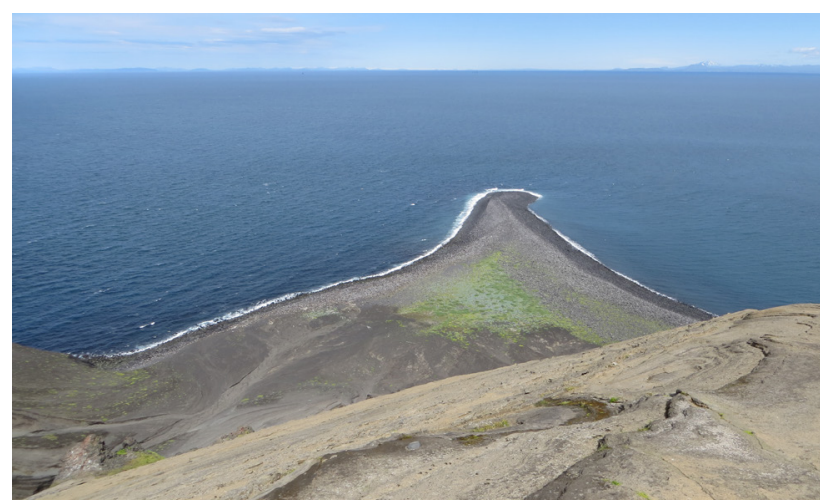

B. 17 July, 2018

Figure 15. An overview of the northern spit of Surtsey, taken from the same spot in 2001 and 2018. Note the shrinking of the spit over the period and change in vegetation cover in the center part. Photos: Sigmar Metúsalemsson and Borgthór Magnússon.

made the highest number of pups seen in a single flight was 67 on 3 October, and the estimated pup production in the colony that year was 134 . The peak of the pupping period in 2017 was 12 October (Granquist \& Hauksson 2019b). The number of pups seen in the colony on 18 October 2019 is close to the maximum number recorded in earlier surveys and it should be expected that a higher number of pups were born over the course of the full pupping period (Table 2).

In the brief visit to the island on 30 October 2019, it was not possible to thoroughly inspect the whole seal colony. However, pups at different development stages were encountered, from newborns to 4-5 week-old pups (Fig. 14), as well as an adult female ready to give birth. This further indicates that at the time of inspection of the colony in mid-October some pups were probably unborn and others might have left for the sea. Very little information on grey seal abundance on Surtsey outside of the breeding period exists, but it can be assumed that the island is used by adult grey seals during their moulting period in the spring. Further, information on harbour seal abundance in Surtsey in other times of the year is very scarce. Harbour seals haul-out on land to a large extent during their pupping period in May-June, and it cannot be ruled out that they use Surtsey more at that time of the year than when the surveys have been carried out. This needs to be taken into consideration when effects of seal abundance on plant succession in Surtsey is discussed.

\section{Nutrient transfer by seagulls and seals}

In an earlier paper (Magnússon et al. 2009) we attempted to estimate the nutrient transfer of the gulls in their colony based on the excretion and food models for gulls developed in the Netherlands by Hahn et al. (2007). A seasonal estimate of a family unit (parents and offspring) for a lesser black-backed gull and a herring gull was around $0.6 \mathrm{~kg} \mathrm{~N}$ and $0.12 \mathrm{~kg}$ P. Taking into account the larger size of the great black-backed gull we here approximate the nutrient input of its family unit to $1 \mathrm{~kg} \mathrm{~N}$ and $0.2 \mathrm{~kg}$ P during the breeding season. Therefore, from their nesting density by the plots on the spit in 2015-2019 (0.5-3 nests/1000 $\mathrm{m}^{2}$ $=5-30$ nests/ha) we estimate their nutrient input as $5-30 \mathrm{~kg} \mathrm{~N} / \mathrm{ha}$ and $1-6 \mathrm{~kg} \mathrm{P} / \mathrm{ha}$ in a season. This can be compared to an estimated input of 6-60 kg N/ha and $1.2-12 \mathrm{~kg} \mathrm{P} / \mathrm{ha}$ in a season in the old gull colony during 2003-2008 (Magnússon et al. 2009). Also to measured average seabird $\mathrm{N}$-accumulation of $47 \mathrm{~kg}$ $\mathrm{N} / \mathrm{ha} / \mathrm{yr}$ in the old gull colony soils on Surtsey since 1985 and 1-2 kg of background N-deposition outside the colony (Leblans et al. 2014). The nutrient input of the nesting great black-backed gulls on the northern spit in the last few years is therefore substantial and contributes to the increase in vegetation in the area.

Grey seals are capital breeders as they forage and build up stored blubber that is utilized during the period of breeding and weaning of pups. During this time, they do not forage for food. In mid-September, grey seals start hauling out to breed on the northern spit of Surtsey and the first pups are born. The last females give birth in November-December (Hauksson 2015, Granquist \& Hauksson 2019b). The lactation period is short and the pups are abruptly weaned after 2-3 weeks after which a post-weaning land based fasting period starts. During this period the pup moults before going to sea (Fedak \& Anderson 1982). After 
weaning the females mate with the dominant male. Knowledge on grey seal pup development and exact time spent at the breeding site at these different stages is scarce for the Icelandic population. However, in a study of breeding grey seals (17 mothers and pups) on Sable Island, Canada, the average lactation period was 17 days. The average weight of a female at the time of parturition was $196 \mathrm{~kg}$ and pup birth mass 17 $\mathrm{kg}$. At the time of weaning a pup had increased its weight $200-300 \%$ and the females had lost $35 \%$ of their initial body mass (Mellish et al. 1999). Further, Reilly (1991) studied the post weaning fast period of 12 grey seal pups. Their fast period lasted from 10 to more than 28 days. However, among 8 pups that were studied more thoroughly, the average post weaning fast lasted for 16 days on the average.

Can it be assumed that a $200 \mathrm{~kg}$ grey seal female and its pup transfer more nutrients from sea to land than a pair of black-backed gulls $(2 \times 2.5 \mathrm{~kg})$ breeding in the same area? Water and energy metabolism of free-living grey seal pups during their post-weaning fast was studied by Reilly (1991). The average water output of the pups was $521 \mathrm{ml} /$ day. The daily urine output fell with fasting time, from 4.8 to $2.1 \mathrm{ml} / \mathrm{kg} /$ day. Nitrogen in pup urine was $3.4 \mathrm{~g} /$ day $(24 \mathrm{~h})$ at initial capture but fell to $1.8 \mathrm{~g} /$ day at final capture (Reilly 1991). These values can be used to speculate about the possible nutrient output from the seals on Surtsey. Assuming a female/pup weight ratio of 6 over the period of lactation (17 days), (Mellish et al. 1999), the same urine output per $\mathrm{kg}$ and the higher urine $\mathrm{N}$-value (3.4), a post weaning period of 16 days (Reilly 1991) and the N-output value for the pups as $2.6 \mathrm{~g} \mathrm{~N} /$ day over the period (average of the higher and lower value found by Mellish et al. 1999). The outcome will therefore be: female lactation period 6 x $3.4 \mathrm{~g} \mathrm{~N} /$ day x 17 days $=347 \mathrm{~g} \mathrm{~N}$; pup lactation period $3.4 \mathrm{~g} \mathrm{~N} /$ day $\times 17$ days $=58 \mathrm{~g} \mathrm{~N}$, pup post weaning period $2.6 \mathrm{~N} /$ day $\times 16$ days $=42 \mathrm{~g} \mathrm{~N}$. This exercise gives a total nitrogen output from a female and its pup of $447 \mathrm{~g} \mathrm{~N}$, assuming that the females urinate on land only during the period of lactation. Feces from the females and the pups are not included, but defecation appears to be limited during the period of fasting (Reilly 1991). The N-output from a grey seal female and its pup estimated here is therefore only about half of the estimated output from a pair of black-backed gulls and their chicks.

As stated above, there were 62 grey seal pups and 32 adults seen on the northern spit of Surtsey in
October 2019. Considering that the estimated pup production in 2017 was estimated to 134 , it is likely that over the whole 2019 breeding season there were more than 100 pups born in the colonly, in an area of approximately 5 ha. The N-output from the seals could therefore be of the order 20-30 females with pups per ha $\times 0.45 \mathrm{~kg} \mathrm{~N}=9-13 \mathrm{~kg} \mathrm{~N} / \mathrm{ha}$, compared to to the 1-2 $\mathrm{kg}$ of background $\mathrm{N}$-deposition on most of Surtsey (Leblans et al. 2014).

The grey seals breed in the fall after the period of vegetation growth. A portion of nutrients coming from the seals to the top soil may be washed or leached away from the plant root zone and not be as readily available as nutrients released from breeding seagulls in the spring and summer. However, as mentioned above, data on grey seal abundance during other periods of the year, such as the moulting period in the spring, is lacking. There are other possible sources of nutrients associated with the seals. When giving birth the females release the placenta and its fluids which are a sources of energy and nutrients and appear to attract seagulls (see earlier). Also, they may release feces at the site before giving birth. At moulting the pups change coats and the birth hairs are left in place, some of them will blow away but others be buried in the sand, eventually decomposing and adding nutrients to the soil. Here we have not considered the males present in the breeding colony and their possible inputs. Another source of nutrients are animals that die on land. In the summer of 2019 three carcasses of long-dead seals were encountered on the western spit of Surtsey. To our knowledge dead seals have not been found previously on the spit, although it can be expected that some of the pups do not survive.

Earlier studies (e.g. Farina et al. 2003, Doughty et al. 2016, Moss 2017, Bokhorst et al. 2019) have suggested that marine mammals and seabirds can be important vectors of marine nutrients to terrestrial systems. Our results support these findings. The animals obtain their food from productive oceans and breed on islands or in other remote areas. At the breeding sites soil nutrient concentrations are affected and plant growth enhanced. These effects have become very clear in the continuing studies of plant colonization and ecosystem development on Surtsey. The seagulls are more mobile than the seals, so they exert their influence over a much larger area on the island. 
With continued erosion of Surtsey the northern spit will probably disappear before the turn of this century, while the island core will remain for thousands of years (Jakobsson et al. 2000). As the older neighboring islands, Surtsey will be girthed by high cliffs and not accessible to seals. Their impact on the island ecosystem will therefore be far more short-lived than that of the seabirds.

\section{ACKNOWLEDGEMENTS}

The Surtsey Research Society has provided logistic support for the study. Transport to the island has been provided by the Icelandic Coast Guard and the Vestmannaeyjar Rescue Team. Anette Th. Meier made maps of vegetation and seal distribution. Bjarni D. Sigurdsson, Erling Ólafsson, Matthías V. Alfredsson, Niki Leblans, Pawel Wasowicz, Sigurdur H. Magnússon and Starri Heidmarsson have taken part in biological expeditions to the island in recent years and contributed in various ways. Erlingur Hauksson provided valuable information on the grey seals. Aerial survey of the island in October 2019 was made with Úlfar Henningsson at Gardaflug. Eric dos Santos made valuable comments and corrections on the manuscript.

\section{REFERENCES}

Aerts, R., R.S.P. Van Logtetijn, N.I.W. Leblans \& B.D. Sigurdsson, 2020. Effects of seabirds and soil development on plant and soil nutritional parameters after 50 years of succession on Surtsey. Surtsey Research 14, 85-90.

Astthorsson, O.S., A. Gislason \& S. Jonsson, 2007. Climate variability and the Icelandic marine ecosystem. Deep-Sea Research 54, 2456-2477.

Ball, B.A., C.R. Telliz \& R.A. Virginia, 2015. Penguin activity influences soil biogeochemistry and soil respiration in rookeries on Ross Island, Antarctica. Polar Biology 38, 1357-1368.

Biological Records Centre (BRC), 2020. Online Atlas of the British and Irish Flora. https://www.brc.ac.uk/plantatlas/ (accessed January 26, 2020).

Bokhorst, S., A. Huiskes, P. Convey \& R. Aerts, 2007. External nutrient inputs into terrestrial ecosystems of the Falkland Islands and Maritime Antarctic region. Polar Biology 30, 1315-1321.

Bokhorst, S., P. Convey \& R. Aerts, 2019. Nitrogen inputs by marine invertebrates drive abundance and richness in Antarctic ecosystems. Current Biology 29, 1721-1727.

British Ornithologists' Union (BOU), 2013. The British List: a checklist of birds of Britain, $8^{\text {th }}$ Edn., Ibis, 155, 635-676.
Doughty, C.E., J. Roman, S. Faurby, A. Wolf, A. Haque, E.S. Bakker, Y. Malhi, J.B. Dunning Jr. \& J.-C. Svenning, 2016. Global nutrient transport in a world of giants. PNAS 113, 868-873.

Ellis, J.C. 2005. Marine birds on land: a review of plant biomass, species richness and community composition in seabird colonies. Plant Ecology 181, 227-241.

Ersts, P.J. DotDotGoose (version 1.1.0). American Museum of Natural History, Center for Biodiversity and Conservation. Available from http://biodiversityinformatics.amnh.org/open source/dotdotgoose. Accessed on 1st July 2019.

Farina, J.M., S. Salazar, K.P. Wallem, J.D. Witman \& J.C. Ellis, 2003. Nutrient exchanges between marine and terrestrial ecosystems: the case of the Galapagos sea lion Zalophus wollebaecki. Journal of Animal Ecology 72, 873-887.

Fedak, M. A. \& S.S. Anderson, 1982. The energetics of lactation: accurate measurements from a large wild mammal, the grey seal (Halichoerus grypus). Journal of Zoology 198, 473 -479.

Fridriksson, S., 1975. Surtsey. Evolution of life on a volcanic island. Butterworths, London, 198 pp.

Friðriksson, S., 2005. Surtsey. Ecosystem formed. Varði, Reykjavík, 112 pp.

Friðriksson. S.F. \& B. Johnsen, 1967. The vascular flora of the outer Westman Islands. Societas Scientarium Islandica, Section IV, 37-67.

Georgsdóttir, G.I., E. Hauksson, G. Gudmundsson \& E.R. Unnsteinsdóttir, 2018. Selalátur við strendur Íslands. Fjölrit Náttúrufræðistofnunar 56, 23 pp.

Granquist, S.M. and E. Hauksson, 2019a. Population estimate, trends and current status of the Icelandic harbour seal (Phoca vitulina) population in 2018. Marine and Freshwater Research Institution, HV 2019-36. 22 pp.

Granquist, S.M. \& E. Hauksson, 2019b. Aerial sensus of Icelandic grey seal (Halichoerus grypus) population in 2017. Pup production, population estimate, trends and current status. Marine and Freshwater Research in Iceland, HV 2019-02, 19 pp.

Hahn, S., S. Bauer \& M. Klassen, 2007. Estimating the contribution of carnivorous water birds to nutrient loading in freshwater habitats. Freshwater Biology 52, 2421-2433.

Hauksson, E., 1992. Observations on seals on the island of Surtsey in the period 1980-1989. Surtsey Research Progress Report 10, 41-42.

Hauksson, E., 2009. Seals in Surtsey, the period 1980-2005. Surtsey Research 12, 167-170.

Hauksson, E., 2010. Niðurstöður af talningum útselskópa úr lofti haustin 2005, 2008 og 2009. Áætlaðar stofnstærðarbreytingar útsels við Ísland 2005 til 2008/9. Handrit Rannsjá fjölrit. Nr. 1. $12 \mathrm{pp}$.

Hauksson, E., 2015. Observations on seals on the island of Surtsey in the period 1980-2012. Surtsey Research 13, 4143. 
Havik, G., A. Catenazzi \& M. Holmgren, 2014. Seabird nutrient subsidies benefit non-nitrogen fixing tress and alter species composition in South American coastal cry forests. Plos One 9, 1, e86381, 8 pp.

Hilmarsson, J.Ó., 2009. Fuglalíf Vestmannaeyja (Birdlife of Vestmannaeyjar), in: Vestmannaeyjar, Árbók Ferðafélags Íslands 2009, 28-73, edited by J.V. Sigurðsson, Ferðafélag Íslands, Reykjavík.

Jakobsson, S.P., G. Gudmundsson \& J.G. Moore, 2000. Geological monitoring of Surtsey, Iceland 1967-1998. Surtsey Research 11, 99-108.

Jakobsson, S.P., B. Magnússon, E. Ólafsson, G. Porvarðardóttir, K. Gunnarsson, S. Baldursson \& Æ. Petersen, 2007. Nomination of Surtsey for the UNESCO World Heritage List, edited by: Baldursson,S. \& Á. Ingadóttir, Icelandic Institute of Natural History, Reykjavik, 124 pp.

Kristinsson, H., J.B. Hlíðberg \& P.E. Pórhallsdóttir, 2018. Flóra Íslands. Blómplöntur og byrkningar (The Flora of Iceland). Vaka-Helgafell, Reykjavík, 741 pp.

Leblans, N.I., B.D. Sigurdsson, P. Roefs, R. Thuys, B. Magnússon \& I.A. Jansen, 2014. Effects of seabird nitrogen input on biomass and carbon accumulation after 50 years of primary succession on a young volcanic island, Surtsey. Biogeosciences 11, 4415-4427.

Lindeboom, H.J., 1984. The nitrogen pathway in a penguin rookery. Ecology 65, 269-277.

Magnússon, B. \& S.H. Magnússon, 2000. Vegetation succession on Surtsey during 1990-1998 under the influence of breeding seabirds. Surtsey Research 11, 9-20.

Magnússon, B., Magnússon, S.H. \& S. Fridriksson, 2009. Developments in plant colonization and succession on Surtsey during 1999 - 2008. Surtsey Research 12, 57-76.

Magnússon B., S.H. Magnússon, E. Ólafsson \& B.D. Sigurdsson, 2014. Plant colonization, succession and ecosystem development on Surtsey with reference to neighbour islands. Biogeosciences 11, 5521-5537.

McCune, B. \& M.J. Mefford, 2011. PC-ORD. Multivariate Analysis of Ecological Data, Version 6. MjM Software, Gleneden Beach, Oregon, USA.

McLoughlin, P.D., K. Lysak, L. Debeffe, T. Perry \& K.A. Hobson, 2016. Density-dependent resource selection by a terrestrial herbivore in a response to sea-to-land nutrient transfer by seals. Ecology 97, 1929-1937.

Mellish, J.E., S.J. Iverson \& W.D. Bowen, 1999. Variation in milk production and lactation performance in Grey seals and consequences for pup growth and weaning characteristics. Physiological and Biochemical Zoology 72, 677-690.

Moss, B., 2017. Marine reptiles, birds and mammals and nutrient transfer among the seas and the land: An appraisal of current knowledge. Journal of Experimental Biology and Ecology
$492,63-80$.

Norton, D.A., P.J. Delaange, P.J. Garnock-Jones \& D.R. Given, 1997. The role of seabirds and seals in the survival of coastal plants: lessons from New Zealand Lepidium (Brassicaceae). Biodiversity and Conservation 6, 765-785.

Ólafsson, E. \& M. Ingimarsdóttir, 2009. The land-invertebrate fauna on Surtsey during 2002-2006, Surtsey Research 12, 113-128.

Petersen, G.N. \& T. Jónsson, 2020. The climate of Surtsey. Surtsey Research 14, 9-16.

Petersen, Æ., 2009. Formation of a bird community on a new island Surtsey, Iceland. Surtsey Research 12, 133-148.

Reilly, J.J., 1991. Adaptations to prolonged fasting in free-living weaned gray seal pups. American Journal of Physiology 260, 677-690.

Rouse, J.W., R.H. Haas, J.A. Schell \& D.W. Deering, 1974. Monitoring Vegetation Systems in the Great Plains with ERTS. In: Third Earth Resources Technology Satellite-1 Symposium. Volume 1: Technical Presentations, section A. https://ntrs.nasa. gov/archive/nasa/casi.ntrs.nasa.gov/19740022614.pdf

Sigurdsson, B.D. \& N.I.W. Leblans, 2020. Availability of plant nutrients and pollutans in the young soils of Surtsey compared to the older Heimaey and Elliðaey volcanic islands. Surtsey Research 14, 91-98.

Sigurdsson, B.D. \& B. Magnusson, 2014. Ecosystem respiration, vegetation development and soil nitrogen in relation to breeding density of seagulls on a pristine volcanic island, Surtsey, Iceland. Biogeosciences 7, 883-891.

Sigurðsson, I.A. \& S.P. Jakobsson, 2009. Jarðsaga Vestmannaeyja (Geological history of Vestmannaeyjar), in: Vestmannaeyjar, Árbók Ferðafélags Íslands 2009, 14-27, edited by J.V. Sigurðsson, Ferðafélag Íslands, Reykjavík.

Sobey, D.G. \& J.B. Kenworthy, 1979. The relationship between herring gulls and the vegetation of their breeding colonies. Journal of Ecology 67, 469-496. 